\title{
The Samar Counterinsurgency Campaign of 1899-1902: Lessons Worth Learning?
}

\author{
William N. Holden ${ }^{1}$ \\ ${ }^{1}$ University of Calgary, Calgary, Alberta, Canada \\ Correspondence: William N. Holden, University of Calgary, 2500 University Drive NW, Calgary, Alberta \\ T2N-1N4, Canada. E-mail: wnholden@ucalgary.ca
}

Received: August 1, 2013 Accepted: October 4, 2013 Online Published: November 6, 2013

doi:10.5539/ach.v6n1p15 URL: http://dx.doi.org/10.5539/ach.v6n1p15

\begin{abstract}
During the Philippine-American War of 1899-1902, the United States Army's most difficult, and renowned, counterinsurgency campaign was waged on the island of Samar. The Samareño insurgents had a well developed infrastructure and were merciless with those who collaborated with the Americans. The Samarnons made extensive use of the island's rough terrain with heavy forest cover, and raised funds from the island's hemp merchants. The Americans defeated the insurgents by separating them from the population. This was achieved through food restrictions, a strict policy of non-neutrality forcing the people to choose between them or the insurgents, by concentrating the population in camps, by providing benefits to those who cooperated with them, and through skillful use of intelligence to dismantle the insurgent infrastructure. This campaign may have been an excellent demonstration of the principles of counterinsurgency warfare but it inflicted substantial abuses upon the Samarnons and caused long term damage to the island's economy. Given the atrocities associated with the campaign, and its detrimental effects upon the island's economy, one must truly wonder if it provides lessons worth learning.
\end{abstract}

Keywords: Philippines, Samar, counterinsurgency warfare, Philippine-American War

\section{Introduction}

\subsection{Samar: The Dark and Bloody Island}

At the turn of the last century, from 1899 to 1902, the United States of America found itself engaged in a counterinsurgency campaign, in a country on the other side of the world, against a people who had recently ended over 300 years of domination by a waning colonial power only to suddenly find their land coveted by a nascent colonial power. One part of the Philippines where this campaign encountered substantial difficulty was the island of Samar. Brian Linn was referred to by Couttie (2004) as "the foremost American historian studying the Philippine-American War. Linn (2003) wrote "the Samareño guerrillas would prove among the toughest the Americans faced." Linn, (2000) states that the violence on Samar was so ferocious that, for years after the conflict, members of the United States Marine Corps who fought against the Samarnons would be saluted upon their entry into a mess hall with the toast, "Stand Gentlemen, he served on Samar!" This article examines the American counterinsurgency campaign on Samar, from 1899-1902, analyzing the factors leading to its success while also discussing the abuses it inflicted upon the Samareños and the long-term adverse consequences it imposed upon them.

\subsection{The Relevance of This Study}

As a result of the recent conflicts in Afghanistan and Iraq, counterinsurgency warfare has become a topical subject matter. According to Kilcullen (2006), more has been written on counterinsurgency warfare in the last four years than in the last forty. "The vast majority of armed conflict today occurs inside states rather than between them," wrote Nagl (2005), and the conclusion of the Cold War "has returned to the front pages the small wars of the nineteenth century." To Nagl (2005), the Philippine-American War was "the U.S. Army's most successful instance of counterinsurgency theory and practice." The success of the United States in the Philippines offers numerous lessons on counterinsurgency procedure (Linn, 2003). As Couttie (2004) wrote about the Philippine-American War on Samar, "There is plenty of raw material that could, and should, be 
processed into a form that would illuminate the period and become a valuable resource for those concerned with counterinsurgency operations in the post 9/11 era."

\section{Methodology: A Review of the Literature on Insurgency and Counterinsurgency}

\subsection{Insurgency Warfare}

David Galula's 1964 book Counterinsurgency Warfare: Theory and Practice is regarded as a "classic" work on counterinsurgency warfare (United States Army and Marine Corps, 2007). According to Galula (1964), "an insurgency is a protracted struggle conducted methodically, step by step, in order to attain specific intermediate objectives leading finally to the overthrow of the existing order." The United States Army and Marine Corps (2007) define insurgency as "an organized, protracted politico-military struggle designed to weaken the control and legitimacy of an established government, occupying power, or other political authority." To the United States Government (2009), "Insurgency can be defined as "the organized use of subversion and violence to seize, nullify, or challenge political control of a region." The "main effort" of insurgents, wrote the United States Government (2009), "is not to kill counterinsurgents, but rather to establish a competitive system of control over the population making it impossible for the government to administer its territory." Grievances, sources of discontent motivating people to take up arms and attempt to achieve change violently, are an important impetus to an insurgency (United States Army and Marine Corps, 2007). An important variant of insurgencies are resistance movements wherein indigenous elements seek to expel, or overthrow, a foreign or occupation government (United States Army and Marine Corps, 2007). The grievance fuelling a resistance movement is the intervention by a foreign power and its attempt at imposing foreign rule.

\subsection{Counterinsurgency Warfare}

"Counterinsurgency" is defined by the United States Army and Marine Corps (2007) as "military, paramilitary, political, economic, psychological, and civic actions taken by a government to defeat insurgency." According to the United States Government (2009) "counterinsurgency may be defined as comprehensive civilian and military efforts taken to simultaneously defeat and contain insurgency and address its root causes." Victory is achieved in counterinsurgency when the population consents to the government's legitimacy and stops supporting the insurgency (United States Army and Marine Corps, 2007).

\subsection{The Importance of Terrain in Insurgency Warfare}

Insurgencies thrive where there is rough terrain and heavy forest cover; the former makes it harder for the counterinsurgent to move against the insurgent and the latter provides concealment for the insurgent. As Kalyvas (2006) stated:

A striking and recurring feature of irregular war is how space shapes control. Towns, plains, key communication lines, and accessible terrain in general tend to be associated with incumbent control, whereas mountains and rugged terrain are generally insurgent strongholds; the location of insurgents is best predicted by variables such as terrain and distance from provincial military bases.

\subsection{Insurgent Sources of Funding and Weapons}

To some extent, all insurgencies require funding (United States Army and Marine Corps, 2007). "Money," wrote Galula (1964) is the sinew of war." Insurgent groups acquire their funding by levying "taxes" upon businesses operating in areas where they have influence; should these businesses refuse to pay these "taxes" they will have their facilities destroyed and will be unable to continue operating. Insurgents acquire their weapons by ambushing small parties of government troops and taking the weapons of the dead or wounded soldiers (United States Army and Marine Corps 2007). The logistical problems of insurgents are solved by the enemy becoming the principal source of weapons, equipment, and ammunition (Griffith, 1961, 2005).

\subsection{The Importance of Separating Insurgents from the Population}

For the counterinsurgent, victory is measured by two metrics: the destruction of insurgent forces and the isolation of the insurgent form the population (Galula, 1964). Sir Robert Thompson's 1966 book Defeating Communist Insurgency: the Lessons of Malaya and Vietnam is also regarded as a "classic" work on counterinsurgency warfare (United States Army and Marine Corps, 2007). According to Thompson (1966), it is essential "to isolate the insurgent both physically and politically from the population." "Only when this isolation is effected," stated Thompson (1966), "will successful operations against the [insurgent] units achieve a lasting result." 
Separating the insurgents from the population is a stark process where members of the population are forced to determine which of the two competing sides (insurgent or counterinsurgent) offers them a better chance of survival. If members of the population feel they are more likely to live if the insurgent succeeds, they will support the insurgency; conversely, if they feel they are more likely to live if the counterinsurgent succeeds, they will support the counterinsurgency. "The population's attitude," wrote Galula (1964), "is dictated not so much by the relative popularity and merits of the opponents as by the more primitive concern for safety." The side that provides the best protection, and seems the least threatening, will receive the population's support (Galula, 1964).

Counterinsurgency warfare doctrine is clear that, for a population living in an area affected by an insurgency, neutrality is not an option (Bruno, 2010; Galula, 1964; Thompson, 1966). The population can either support the insurgent or it can support the counterinsurgent but it cannot support both. Counterinsurgents must not tolerate neutrality and they must force the population to choose which of the two sides its loyalty will adhere to (Bruno, 2010).

\subsection{The Importance of Intelligence to a Counterinsurgency}

Intelligence is crucial in counterinsurgency. To Nagl (2005), counterinsurgency is "a task more akin to breaking up a Mafia crime ring than dismantling a conventional enemy battalion or brigade." Counterinsurgency makes the intelligence organization assume paramount importance and defeating an insurgency requires well-trained and highly experienced intelligence officers (Thompson, 1966). Kalyvas (200) discussed the importance of intelligence stating:

The advantages guerrillas and terrorists may possess in opposing the far greater resources of the government can largely be countered if the government has adequate intelligence. Whatever advantages of mobility, surprise, and esprit de corps the guerrilla possess can usually be more then offset if the government has the crucial intelligence at the right moment.

However, in an activity as intelligence intensive as counterinsurgency, the only thing worse than having no intelligence organization is to have an overloaded intelligence organization; if information is coming in so quickly that it cannot be digested and prioritized then it is of little use (Thompson, 1966).

\section{The Philippine-American War on the Island of Samar}

\subsection{The Philippine-American War: The United States Comes to Southeast Asia}

The Philippines, an archipelago of approximately 7,100 islands located in Southeast Asia (Figure 1), was a colony of Spain from 1568 to 1898 . The Spanish colonial era was by no means tranquil and it was marked by numerous peasant uprisings. On the island of Bohol, for example, the Spanish lost complete control from 1744 until 1829 when peasants established mountainous communities and openly defied them (Constantino, 1975). 


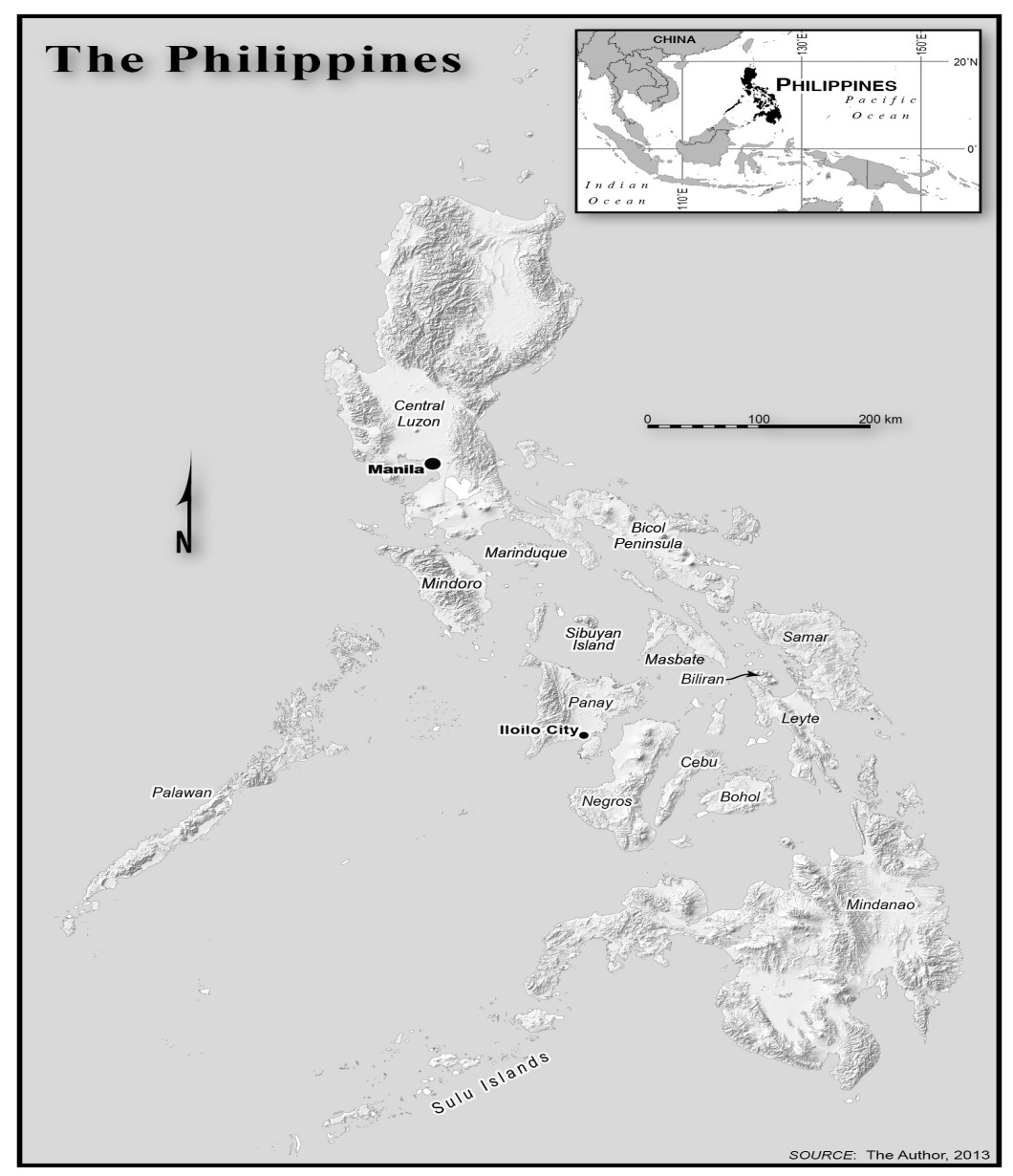

Figure 1. The Philippines

However, as the twentieth century approached the conditions faced by the peasantry began worsening; as Linn $(2000,16)$ wrote, "By the 1890 s much of the Philippines was in severe distress, plagued by social tension, disease, hunger, banditry and rebellion." In 1896, the Philippine Revolution broke out, largely under the leadership of Andres Bonifacio, a man of lower-middle class background, and his Katipunan society (Constantino, 1975). In 1897, a wealthy land owner named Emilio Aguinaldo had Bonifacio killed and took over the leadership of the revolution (Silbey, 2007). In December of 1897, Aguinaldo and forty of his followers reached an agreement with the Spanish to go into exile in Hong Kong in exchange for the payment of $\$ 800,000$ half to be paid in advance and the other half to be paid upon their arrival in Hong Kong (Miller, 1982).

On 25 April 1898, in a conflict of very vague origins, the United States and Spain went to war and on 1 May 1898 the United States Navy annihilated the Spanish fleet at the Battle of Manila Bay (Silbey, 2007). With the end of Spanish control appearing imminent, Aguinaldo returned to the archipelago on 19 May 1898 to resume the revolution and on 12 June 1898 the independence of the Republic of the Philippines was declared (Francia, 2010). However, two weeks after the Filipinos declared their independence, a contingent of United States Army soldiers arrived in the Philippines and it soon became apparent that the Americans intended to retain the archipelago (Miller, 1982). Over the next eight months tension grew as Filipino insurrectos surrounded Manila while the city was occupied by the Americans. Eventually conflict broke out between the two forces on 4 February 1899 and by 13 November 1899, unable to engage in conventional positional warfare against a well equipped and highly trained modern army, Aguinaldo ordered his forces to switch to guerrilla warfare, which continued after his capture on 23 March 1901 until 1902 (Boot, 2002). This insurgency was most pronounced on the island of Samar ${ }^{1}$ and it is to this dark and bloody island that attention now turns.

\subsection{The Island of Samar: Setting the Stage}

"For most of its history," wrote Cruikshank (1982), "the island of Samar has been a backwater." Along with Biliran and Leyte, Samar (Figure 2) is located in what is known as the Eastern Visayas region of the Philippines 
(Santos \& Lagos, 2004). The island, having derived its name from the Waray-Waray (the principal language of the Eastern Visayas) word samad ("wound"), has a land area of 14,401.13 square kilometers, is the third largest island in the Philippines, and constitutes approximately five percent of the archipelago's land area (Santos \& Lagos, 2004).

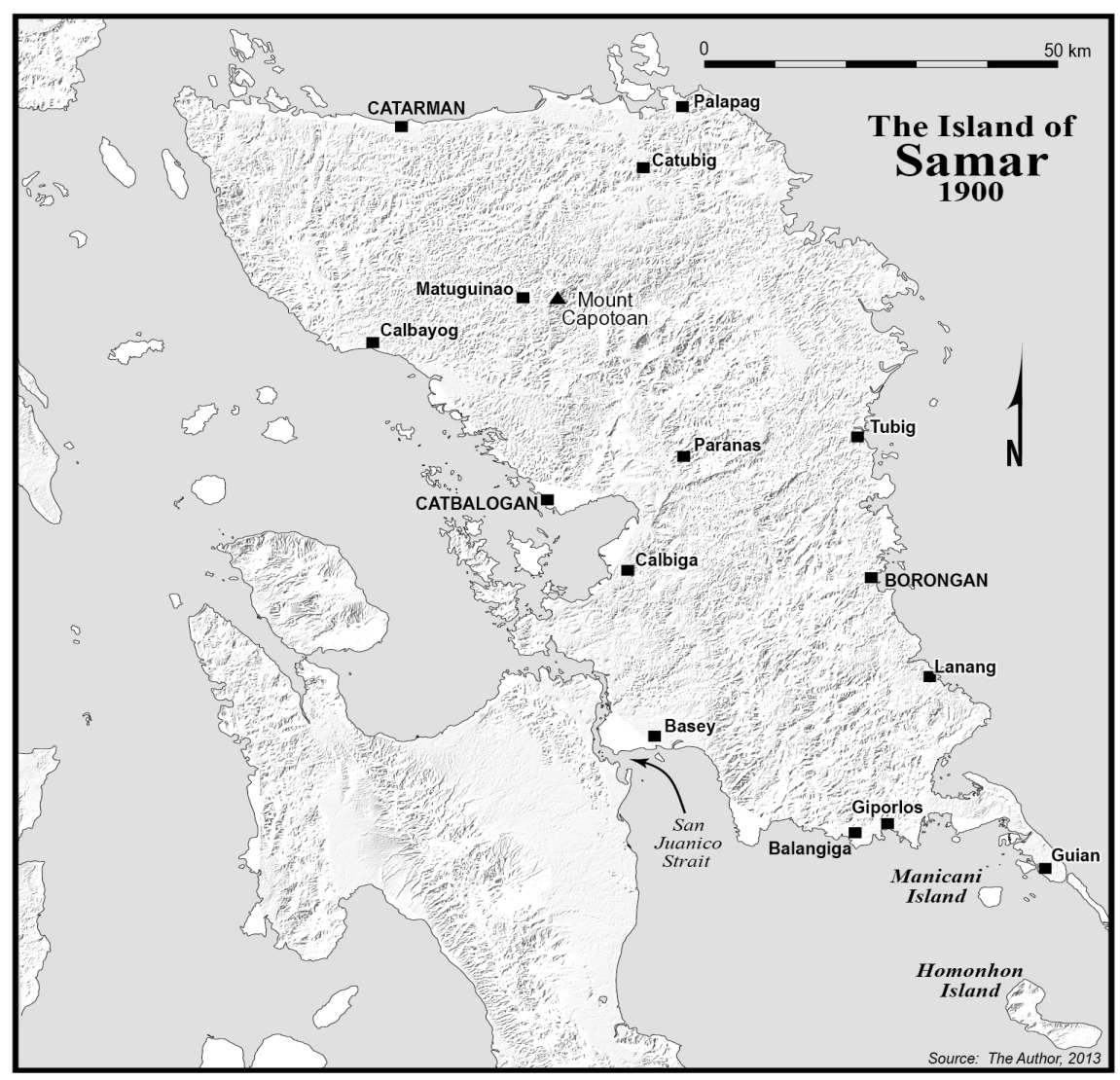

Figure 2. The island of Samar Circa 1900

In terms of terrain, Couttie (2004) described Samar as an "island of moderate mountains and lush rainforest sliced through by rivers connecting the interior and the coast." According to Linn (1993), the island is "divided into a narrow coast region and a rugged series of mountains and river valleys that cover most of the interior." Although the mountains on Samar are lower (between 200 meters and 800 meters) than on other islands in the Philippines, Samar's terrain is rugged and hilly and two-thirds of its land area has a slope of over 18 degrees (Santos \& Lagos, 2004). Some of the roughest terrain on the island is found between Calbiga and Borongan, where there are numerous boulders and limestone deposits with an extensive cave system (Haribon Foundation and Birdlife International, 2001).

Samar has a wet climate, receiving over 3,000 millimeters of rainfall every year and, consequently, is covered with tropical rainforests (Santos \& Lagos, 2004). In Figure 3 the island's forest cover in 1900 is displayed and, at the time of the Philippine-American War, Samar was covered by an extensive tropical rainforest. This caused Gates (1973) to describe the island's interior as a wild jungle "crossed only by poorly marked trails." "No roads penetrated the island's heartland, and its few rivers were unsuitable as avenues of advance" (Gates, 1973). Linn (2008) described Samar as "replete with rugged mountains, jungles, tortuous rivers, razor-sharp grasses, swamps, and parasites."

In 1900, Samar had a population of 312,192 people, which constituted approximately 16 percent of the archipelago's population of two million people (Gates, 1973; Young, 1979). The population of Samar is overwhelmingly Christian with there being no appreciable Muslim population and there being virtually no indigenous peoples (those with a historical continuity with the pre-Islamic and pre-Hispanic religions of the archipelago) residing in the Eastern Visayas (Holden, 2012). During the nineteenth century, abaca, coconuts, and rice were the primary concerns of the Samarnons and their sources of flood, clothing, and commerce 
(Cruikshank, 1982). However, during the latter half of that century abaca (Musa textilis- the plant from which hemp is produced) began to eclipse all other crops and abaca exports from Samar increased, on average, by 13 percent a year between 1851 and 1870 (Cruikshank, 1982). Samar is vulnerable to typhoons, which form south and east of the Philippines and track in a northwesterly direction impacting Samar, the Bicol region of southeast Luzon, and northern Luzon (Holden \& Jacobson, 2012). The destructive effects of the high winds and heavy rainfall associated with typhoons destroy infrastructure and crops, particularly abaca (which is highly vulnerable to strong winds).

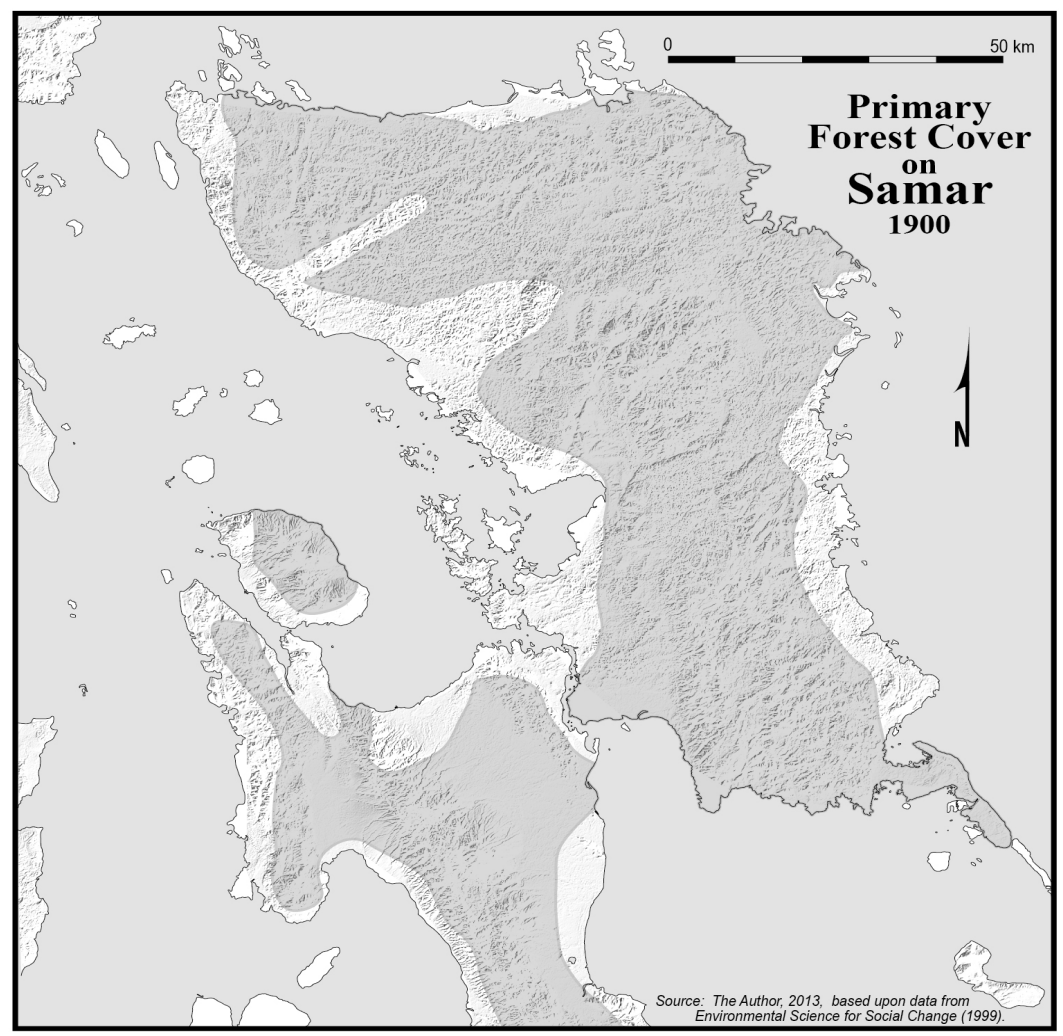

Figure 3. Primary forest cover on Samar in 1900

Historically, there have been "deep and bitter divisions among various sections and classes in Samareño society" (Linn, 2008). Samarnons have been divided into two continually feuding groups: uplanders and lowlanders (Tiston, 1984). The uplanders would raise abaca and then bring it to the coastal areas were the lowlanders would purchase it from them, under terms they dictated, and then export hemp from the island. The ability of the hemp merchants to dictate terms to the abaca producers generated feelings of resentment among the uplanders, which made them resentful towards the lowlanders. Overtime, this tension became mollified by the development of customary laws governing hemp production but it always remained beneath the surface (Couttie, 2004; Cruikshank, 1982).

Samar did not have a history of unrest dating the Spanish colonial period with the notable, and important, exception of the Sumoroy rebellion of 1649 to 1650 (Cruikshank, 1982). During this time the extraction of forced labor, particularly for the falling of trees and the building of ships, disrupted the people's livelihoods. The Sumoroy rebellion broke out in Palapag, when the people rose up under the leadership of Juan Ponce Sumoroy against the demands of the Spanish shipbuilders (Couttie, 2004). The revolt spread across Samar, north to Bicol, and south to Mindanao (Couttie, 2004).

\subsection{The Insurgency on Samar}

The leader of the insurrectos on Samar was Vicente Lukban, a Justice of the Peace from Bicol (Couttie, 2004). Lukban, a member of Aguinaldo's revolutionary junta, went into exile with Aguinaldo in Hong Kong. After Lukban returned to the Philippines in 1898 he served with distinction fighting against the Spanish in Bicol before being ordered to Samar in April of that year to administer the island for the revolutionary government; when conflict broke out with the Americans he became the island's military governor. Lukban was a highly effective leader of the insurgency against the United States. Lukban had an acute understanding of guerrilla warfare, knew 
how to marshal resources, live off the land, and how to make the most of the surrounding environment (Couttie, 2004).

Lukban showed no mercy to those who collaborated with the Americans. According to Linn (1991), "Samareño guerrillas buried three collaborators alive, slaughtered one suspect's family, lashed another man to a tree and hacked him to death, and hamstrung, whipped, or cut the ears off Filipinos who had guided soldiers." In the words of Miller (1982):

Any Samareño suspected of collaborating with the Americans was executed in dramatic fashion as a lesson to other that Lukban still controlled the island. The head of one official who cooperated with the invaders was wrapped in a kerosene-soaked American flag and set on fire.

When the Americans first arrived on Samar, Lukban made no effort to immediately contest them and quietly retreated into the interior, leaving behind a well-organized network of officials and Filipino priests loyal to him (Miller, 1982). The first confrontation between Lukban's forces and the Americans occurred on 11 March 1900 when 150 bolo (knife) wielding insurrectos attacked 11 soldiers from the $3^{\text {rd }}$ Battalion of the $43^{\text {rd }}$ Infantry Regiment at Paranas; three Americans were killed and there were 150 Samareño casualties (Couttie, 2004). On 15 April 1900, 600 Samarnons attacked 31 men, also from the $43^{\text {rd }}$ Infantry, at Catubig; 14 Americans and 150 Samarnons were killed (Roth, 1981). On 23 June 1901, a 26 man patrol of the $1^{\text {st }}$ Infantry Regiment attempted to find an overland route from Guiuan, on the southeastern tip of Samar, when it was ambushed by, what Linn (2000) called, "a horde of bolomen." Two soldiers were killed and another two were wounded; the survivors abandoned their dead and ran for their lives. Throughout September and October the insurrectos carried out sporadic raids, attacking supply trains, besieging towns, and ambushing isolated detachments of American troops (Linn, 2000). Then on 28 September 1901 the most notorious event of the entire Philippine-American War occurred in Balangiga.

During May of 1901 Pedro Abayan, the Mayor of Balangiga, wrote to General Adna Chaffee, the commander of American forces in the Philippines, requesting troops to protect Balangiga from Muslim pirates operating out of the Sulu islands (Miller, 1982). Consequently, on 11 August 1901, Company C of the $9^{\text {th }}$ Infantry Regiment was deployed to Balangiga (Couttie, 2004). Then, during that same month, Abayan wrote to Lukban advising him that the residents of Balangiga would pursue a fictitious policy with the Americans upon their arrival and, when the time was right, would rise up against them (Gates, 1973). On the morning of Sunday 28 September 1901, while the men of Company $\mathrm{C}$ were having breakfast in their mess tent, this plan came to fruition and insurrectos attacked them with bolos (Francia, 2010). Both officers and 46 enlisted men were killed; 22 other soldiers were wounded and only four soldiers emerged unscathed (Boot, 2002). The survivors of the attack, many of them badly wounded, staggered to the beach, boarded boats, and fled to Basey, on the west coast; all along their route they were harassed and attacked at any attempted landfall (Couttie, 2004). According to Miller (1982), "No single event in the Philippine war shocked the American people as did the massacre at Balangiga." "It was," wrote Miller (1982), "the worst disaster for the United States Army since Custer's fate at Little Big Horn." "Balangiga," wrote Boot (2002), "was the worst set back for US forces during the entire war."

One thing the Samareño insurgents excelled at was an exploitation of the island's topography; as Linn (1993) stated, "the insurgents combined effective guerrilla tactics with a through knowledge of Samar's terrain." The rugged topography of Samar offered an ideal sanctuary for the insurrectos with much of the island being unfavorable for military maneuver (Tiston, 1984). According to Young (1979), "The island, composed of rugged mountains, dense jungles, mango swamps, and swift rocky rivers, was ideal for guerrilla warfare." In the opinion of Linn (2008) the importance of Samar's topography "cannot be overemphasized." An important example of this was the inability of the Americans to use cavalry on Samar. In other parts of the Philippines, such as the plains of Central Luzon, the Americans made effective use of cavalry with its rapid mobility (May, 1987). Samar's topography, wrote Couttie (2004), was "supremely inappropriate for horse born troops." The insurrectos would augment the advantages presented by the terrain with developing sophisticated traps to prevent American forces from engaging in surprise attacks; as Linn (1993) wrote, "They specialized in mantraps, ranging from bamboo stakes and spring-driven spears, to baskets filled with logs and rocks, effectively preventing soldiers from surprise marches or night operations."

One of the most impressive aspects of Lukban's insurgency was its ability to raise funds (Couttie, 2004; Gates, 1973). On Samar there were British trading houses engaged in the hemp trade. Lukban would levy taxes upon these hemp merchants and, in exchange for providing the insurrectos with food and funds, they would be allowed to continue purchasing hemp; according to Couttie (2004), "Lukban's covert use of an 
economic/industrial system in this way mirrors strategies used today by nonconventional, insurgency-style groups." The insurrectos also displayed an adroit ability to seize weapons from American troops after their attacks; at Balangiga, for example, they acquired 100 rifles and 25,000 rounds of ammunition (Gates, 1973).

Given their well developed insurgent infrastructure, ruthless treatment of collaborators, ferocious attacks on American units, skillful use of the island's terrain, and ability to raise funds, it is not surprising that Bruno (2010) called the insurgency on Samar, “one of the most thoroughly ingrained insurgencies in the archipelago's most rugged terrain." Silbey (2007) described the insurgency on Samar as something causing it to gain "a reputation as a fierce and dangerous place." Miller (1982) stated the Samarnons acquired a reputation as being "ferocious, fanatical, and treacherous." Attention now turns to the campaign waged by the United States to suppress this insurgency.

\subsection{The American Counterinsurgency Campaign: A Typhoon of Steel}

Originally Samar had been assigned to the United States Army's Department of the Visayas, headquartered in Iloilo City, on the Island of Panay. Then, in July 1900, Samar was reassigned to the Department of Southeastern Luzon, in Bicol. Finally, in May 1901, Samar was assigned back to the Department of the Visayas (Linn, 2000). The Army might very well have ignored Samar completely but in January 1900 President McKinley insisted that the hemp ports of Calbayog and Catbalogan be opened and, consequently, troops were deployed there (Linn, 2000). For an aspiring naval power like the United States, hemp had a high strategic importance; in the words of Couttie (2004), "to its shiny new navy and growing merchant marine, hemp was only slightly less important than water." From January 1900 until May 1901 the small deployment of troops on the island did little other than occupy Calbayog and Catbalogan. However, as incursions of Lukban's insurrectos across the narrow San Juanico Strait onto Leyte interfered with the handover of that island to civilian administration under the Philippine Commission, the decision was made to return Samar to the Department of the Visayas "with instructions to take 'drastic measures' against Lukban" (Linn, 2000). After the massacre at Balangiga efforts to eradicate the insurgency were accelerated and the Sixth Separate Brigade, consisting of 4,000 soldiers and 300 marines, was sent to Samar under the command of Brigadier General Jacob ("Hell Roaring Jake") Smith, a veteran of the Wounded Knee Massacre (Linn, 2000; Miller, 1982). Couttie (2004) described the deployment of the Sixth Separate Brigade on Samar as "a typhoon of steel."

The first thing the Americans did to attack the insurgency was to engage its members in combat (Bruno, 2010). On Samar, the Americans quickly concluded that large-scale cordon and sweep operations were ineffective (Bruno, 2010). Samar's rough terrain allowed the insurrectos to detect the approach of large-forces through the limited avenues of approach and this allowed them to move their encampments. Instead of large-scale cordon and sweep operations, small-scale reconnaissance-in-force operations consisting of from 50 to 100 men were implemented at night and, after insurrectos camps were located, attacks would take place at dawn. These operations were well facilitated by a string of supply dumps the army had constructed across the island facilitating long-range patrols (Linn, 2008).

In addition to engaging the insurgents in combat the Americans placed a heavy emphasis upon separating them from the population. The army implemented a ruthless scorched earth policy to deny the insurrectos food and the navy implemented a blockade of all of the island's ports preventing any food from being imported (Linn, 1993, 2000). The thinking behind this was that if the people had barely enough to eat they would be unwilling to supply the insurgents with food; as Bruno (2010) wrote, "Starving natives would be hard pressed to donate foodstuffs to the insurgency." The destruction and interdiction of food supplies had two effects: first, it caused Samar's towns to become filled with hungry civilians, many of them eager to cooperate with the Americans; second, it made life in the interior of the island's jungles extremely difficult for the insurrectos (Linn, 2000). As Bruno (2010) wrote, "The devastation of the countryside literally 'starved-out' the insurgents."

The army also acted to separate the insurgents from the population by implementing a concentration camp system, an emulation of the reconcentrado method used by the Spanish in Cuba, and a foreshadowing of the strategic hamlet program implemented years later during the American War in Vietnam (Francia, 2010). It is estimated that up to 10 percent of all Samarnons was kept in these concentration camps (McCoy, 2009). To Bruno (2010), putting people in concentration camps gave the Americans "the ability to target nearly any native outside the camps based on the theoretical presumption that he was an insurgent, or an insurgent sympathizer." According to Bruno (2010), "Outside the concentration camps, the army devastated the countryside to complete the isolation of the insurgents. Shelters, crops, farm animals, and supplies throughout the countryside were confiscated or destroyed." 
The concentration camps also provided security for those Samareños who desired protection by the Americans from the insurgents, something that made it more difficult for people to claim neutrality between the Americans and the insurrectos (Bruno, 2010). Smith was adamant that, in a choice of loyalties between the Americans and the insurgents, neutrality was not to be tolerated; everyone would be regarded as a friend or as an enemy (Bruno, 2010). Smith's officers were directed to provide security for inhabitants seeking peace; future sympathizers would receive no exemption from punishment by claiming that their acts were performed under duress (Bruno, 2010).

The Americans also sought the support of upper-class Samareños, those who had the most to lose as the war continued. "On Samar," wrote Linn (2003), "the Americans raised a scout unit from among the hemp merchants who were losing both economic and political power as a result of insurgent exaction." By recruiting Samareño volunteers, promising local autonomy, and offering generous surrender terms, the Army began providing attractive alternatives to resistance (Linn, 2008). Food restrictions, intolerance of neutrality, security through population concentration, and benefits for providing cooperation, all placed the Samarnons in the position of having to choose sides between the insurgency and the Americans. These programs allowed the Americans to separate the insurgents from the population. The Americans succeeded through their ability to separate the population from the insurrectos and to co-opt the local leadership (Couttie, 2004).

Another important component of the counterinsurgency campaign on Samar was intelligence. The massacre at Balangiga, wrote Linn (1991), "revealed the failings of an appallingly unprofessional intelligence organization." Balangiga demonstrated an egregious intelligence failure for two reasons: first, the Americans should have detected the ruse inherent in Abayan's request for troops to protect Balangiga from Muslim pirates because such attacks had become practically nonexistent over the preceding half century; second, during August of 1901, Americans soldiers captured the letter sent by Abayan to Lukban advising him of the plan to attack the American troops in Balangiga (Miller, 1982). However, after this letter wound its way up the intelligence chain of command it ended up 300 kilometers away at the Department of the Visayas, in Iloilo City, where it remained until being discovered in October 1901- after the Balangiga Massacre (Linn, 1991). After the intelligence failure at Balangiga much of the intelligence activities on Samar were directed by Major Edwin Glenn, the Sixth Separate Brigade's Judge Advocate, who made it his priority to locate the leaders and supporters of the insurgency (Linn, 1991). Using Navy gunboats, Glenn raided coastal towns, seeking evidence that the inhabitants were engaged in smuggling supplies to the insurrectos. Glenn's arrests of merchants and municipal officials, and their resulting relentless interrogations, soon uncovered the names of contributors, smugglers, and couriers (Linn, 1991). Glenn's relentless pursuit of information eventually inflicted mortal wounds upon the civilian support base of the insurgency.

Harassed by small units of American soldiers probing the interior, denied supplies by food destruction and interdiction, separated from the population, and with their movements and locations detected by Glenn's intelligence gathering, the insurgents on Samar could only continue for so long. Eventually, on 18 February 1902, Lukban was captured hiding in the mountains near Matuguinao and by April 1902 the last of his followers had surrendered at Paranas (Couttie, 2004). The insurgency on Samar had been defeated.

In discussing American efforts at "winning hearts and minds" during the Philippine-American war, Gates (1973) lauded the Army writing, "American efforts in organizing municipal government, schools, public health programs, and public works projects helped convince the Filipinos of the sincerity of the American claims to have come to the islands to help the inhabitants." Gates (1973) also declared that, "The American policy of benevolence and the many humanitarian acts of the army throughout the war played a much more important role in the success of the pacification campaign than fear did."2 On Samar, however, the insurgency had not been vanquished through benevolence and, instead, this defeat had been achieved violently with minimal attempts to build roads, found schools, or win over the population (Linn, 2008). In suppressing this insurgency there had been an extremely heavy use of the stick and very little, if any, use of the carrot! A good summary of the conclusion of the Samar counterinsurgency campaign is that provided by Silbey (2007):

By the summer of 1902, the insurgency on the island had been crushed for the most part. The rebel bands that remained were scattered, ill-equipped, and incapable of serious action. American rule, for the most part, was unchallenged. The stringency had worked, at some cost in pain and suffering. How much of that suffering was unnecessary will never be known. 
All victories come at a cost and the costs of this victory were borne heavily by the Samarnons, both in terms of the immediate abuses inflicted upon them and in terms of the long-term damage inflicted upon the island; it is to these costs that focus now shifts.

\section{Discussion: The Price of Victory, Wounding the Wounded Land}

\subsection{Abuses Inflicted by the Americans}

"The struggle for Samar," wrote Linn (1993), "was probably the most vicious, and certainly the most controversial campaign of the Philippine War." To Linn (2000), the Samar campaign was "the longest and most brutal pacification campaign in the Philippine War." From October 1901 to March 1902, the population of the island fell from 312,192 to 257,715- a decrease of almost 18 percent in only five months (Young, 1979).

In particular, the campaign of the Sixth Separate Brigade was exceptionally brutal; Welch (1974) referred to this as "the most widespread killing of Filipino civilians" in the entire war. According to Miller (1982), when Smith gave Major Littleton Waller, the commander of a battalion of Marines assigned to the Sixth Separate Brigade, his orders he said:

I want no prisoners. I wish you to kill and burn, the more you kill and burn the better it will please me. I want all persons killed who are capable of bearing arms in actual hostilities against the United States.

Waller then asked Smith at what age someone would be deemed capable of bearing arms and Smith replied "ten years of age" (Miller, 1982). Smith then ordered Waller to make the interior of the island a "howling wilderness" (Gates, 1973). Waller then attempted to march his Marines across the island from Lanang to Basey; when this proved impossible, due to the rough terrain and heavy forest cover, Waller had twelve Samareño civilians summarily executed for having mislead the marines and for plotting against them (Linn, 2000). Waller and Smith were court-martialed for their abuses; the former was acquitted and the latter received only a letter of reprimand and was forced into retirement (Miller, 1982). Smith's court-martial was significant because it would not be until the 1971 court-martial of Brigadier General John Donaldson, during the American War in Vietnam, that an American general would be court-martialed for war crimes (Turse, 2013).

Glenn, referred to by Linn (2000) as "the brutal brigade provost marshal," also engaged in (what would today be referred to as) substantial human rights abuses. Glenn's efficiency was accompanied by substantial cruelty (Linn, 1991). Intelligence gathering often involved torture and, on one occasion, Glenn had three priests tortured to obtain information about the insurgency (Linn, 1991; Welch, 1974). Glenn would order summary executions and he raided Leyte, which was outside of military jurisdiction, abducted civilians there and returned them to Samar for interrogation, thus causing substantial embarrassment for the military government of Samar (Linn, 1991). Given the abuses inflicted upon the population by of Samar by the Americans one must wonder if a "successful" counterinsurgency campaign involves such widespread abuses is this really a lesson worth learning? Could not a more population-centric method of defeating the insurgency have been implemented, one providing the Samarnons with incentives for supporting the Americans instead of one based on punishing them for supporting the insurgents?

Indeed, an argument can be made that the abuses inflicted upon the Samareños were an example of state terrorism. Blakeley (2009) defines "state terrorism" as "a threat or act of violence by agents of the state that is intended to induce extreme fear in a target audience, so that they are forced to consider changing their behavior in some way." According to Blakeley (2009), state terrorism was widely used during the Philippine-American War to pacify the archipelago; this involved "the use of torture, rape, shootings, hangings, and the systematic burnings of homes and villages all aimed at quelling support for the insurgency."

An interesting example of how the Samar counterinsurgency campaign involved a lesson of controversial value comes from the writing of Thomas A. Bruno, a Lieutenant Colonel in the United States Marine Corps; Bruno (2010) lauds the strategy of the Sixth Separate Brigade stating:

The Army's strategy for the Philippine Insurrection was to make continued guerrilla war seem hopeless and the concept of peace more attractive to the Filipinos. The overall strategy attempted simultaneously to entice the population with a policy of attraction and to coerce it with a policy of chastisement. However, this methodology necessitated augmentation by direct military action. Only after the neutralization of the guerrilla organization's influence, could the policy of attraction be effective (emphasis added). 
The crucial word in the preceding quotation is the word neutralization. By pointing to the Army's "neutralization of the guerrilla organization's influence," as an example of how the Samar campaign provides lessons on successful methods of waging counterinsurgency, Bruno is revealing the influence on the United States military of the Phoenix Program, a program of selective assassinations carried out by the United States during the American War in Vietnam. As Valentine (2000) wrote:

Developed in 1967 by the Central Intelligence Agency, Phoenix combined existing counterinsurgency programs in a concerted effort to 'neutralize' the Vietcong infrastructure. The euphemism 'neutralize' means to kill, capture, or make to defect. The word 'infrastructure' refers to those civilians suspected of supporting North Vietnamese and Vietcong soldiers.

After Vietnam, the United States institutionalized the tenets of Phoenix within its counterinsurgency doctrine (Holden, 2009, 2011). The United States Army Command and General Staff College (1986) Field Circular: Low Intensity Conflict stated, a major consideration of counterinsurgency warfare is "neutralizing the insurgent leadership and the insurgent organization." Then the United States Army and Air Force (1990) Military Operations in Low Intensity Conflict Field Manual highlighted the importance of "neutralizing" insurgents through "physically or psychologically separating insurgents from the people, converting their members, disrupting their organization, or capturing or killing them." Clearly, the destruction of insurgent infrastructure has become an established component of American counterinsurgency doctrine. However, according to McCoy (2009), when such doctrine has been provided by American military advisers to the armed forces of their client states in the developing world, words such as "neutralize" become "words that repressive third world militaries could readily construe as a recommendation for selective assassination." Consequently, this emphasis upon "neutralizing insurgent infrastructure" has been a contributing factor to human rights abuses in the Philippines where the Armed Forces of the Philippines (AFP) have been trained by American military advisers (Holden, 2009, 2011; McCoy, 1999, 2009).

\subsection{Long Term Damage to the Island of Samar}

The Samar campaign resulted in the destruction of the economy of the entire island (Couttie, 2004). To Couttie $(2004,79)$, the Sixth Separate Brigade engaged in "a devastating and destructive campaign" from which "Samar took years to recover, if in fact it ever did." The Americans turned Samar into a "wasteland of destruction" (Couttie, 2004). According to Bruno (2010), the Samar campaign "was based on a harsh policy of devastation and retribution with little attention given to achieving final assimilation of the population." "Shelters, crops, farm animals, and supplies throughout the countryside were confiscated or destroyed" (Bruno, 2010). "Waller," wrote Gates (1973), "reported that in an eleven day span his men had burned 255 dwellings, slaughtered 13 [water buffalos], and killed 39 people." "Waller," stated Miller (1982), "bragged that scarcely a house had been left standing outside the major towns." Roads and bridges had been destroyed, over half of the island's 44 municipalities had been razed to the ground, and 85 percent of all draft animals had been killed (Couttie, 2004). With so much food destroyed malnutrition became widespread and thousands were scavenging for root crops to eat (Couttie, 2004).In the words of Linn (1993):

The cost of the American victory was high. The destruction of crops, boats, and houses, the deportation of civilians to the coast, and the interdiction of outside food supplies by the naval blockade had come close to creating a true 'howling wilderness' of Samar.

By 1902, the Samarnons desperately needed help; if that help had been forthcoming, if the Americans had truly implemented a policy of "benevolent assimilation," providing schools and roads, the island's history might have been different and Samar might have reverted to the conditions it experienced before the war. However, this aid did not come and the island was relegated into becoming the Bloody Samar of legend (Couttie, 2004). If a "successful" counterinsurgency campaign involves the widespread destruction of an entire island's economy one must wonder is it a lesson worth learning? Again, could not a more population-centric method of defeating the insurgency have been implemented?

\subsection{The Entrenchment of the Archipelago's Oligarchic Elite}

Perhaps the most lasting legacy (not just on Samar but also across the Philippines) of the American victory in the Philippine-American War was its entrenchment of the archipelago's oligarchic elite. From the Spanish, the Philippines had acquired a heritage of exploitative colonial rule producing what Birtle (2004) described as an oligarchic society wherein "a small class of wealthy, Hispanized planters and merchants held sway over masses of poor, uneducated subsistence farmers and agricultural laborers." Socioeconomic mobility and democracy 
were unknown, socioeconomic affairs were dictated by patron-client relations, and politics was little more than a vehicle through which the ruling classes competed among themselves for the spoils offered by political power (Birtle, 2004). Into such a setting came the United States Army, anything but a vehicle for social reform.

Land reform was a concept antithetical to several precepts of American culture such as the sanctity of private property, personal responsibility, and aversions to "big government" (Birtle, 2004). Given this, the Americans left untouched the archipelago's deep social problems (Linn, 2000)."American rule," wrote Miller (1982), "did not end the internal class, ethnic, and religious strife, which persist to this day." As Birtle (2004) stated:

In economic matters, the Army's activities were both shaped and limited by the standards of laissez-faire capitalism, while its respect for private property, one of the most sacrosanct of American tenets, prevented officers from dabbling in schemes of land reform that might have helped redress some of the deepest social and economic inequalities of the islands.

However, not only did the Americans fail to reduce the power of the oligarchy they actually increased it. The Americans shrewdly understood that one way to quell the rebellion was to co-opt its leaders (Silbey, 2007). Earlier it was pointed out how Aguinaldo had Bonifacio killed and took control of the revolution against Spain. Aguinaldo and his associates were not interested in mass democracy but, instead, sought an elite controlled republic where they would be in charge. Had Aguinaldo succeeded, the resulting government and society would have resembled a pre-insurgency Philippines in structure and control. The Americans knew that the leaders of the insurgency, the land owning elite, had the most to lose by allowing the war to continue and they ensured that these people would retain their wealth and power if, and only if, they ceased fighting the Americans and accepted American rule of the archipelago. Consequently, the people who were ruling the Philippines before the arrival of the Americans were the same people ruling it after their arrival (Silbey, 2007).

The elite from the Spanish colonial period, frustrated by the refusal of the Spanish to grant them more power, were keen to share power with the new colonialists. When the war ended and civilian rule was established in the islands, they were immediately incorporated into the colonial state apparatus and, from their position at the helm of the government, their economic privileges were preserved (Rodriguez, 2010). The capitalist imperatives of colonial rule caused American officials to enter into close economic relations with the elite maintaining the existing class structure and the status quo of land ownership (Tyner, 2009). Any agitation from the lower classes for wealth redistribution was quickly blunted by the security forces of the colonial state (McCoy, 2009). "The Americans," wrote Karnow (1989), "coddled the elite while disregarding the appalling plight of the peasants, thus perpetuating a feudal oligarchy that widened the gap between the rich and poor." The entrenchment into power of the oligarchy has been a substantial impetus to what McCoy $(2009,20)$ called "the contemporary plight of endless poverty and mass desperation."

On Samar, American rule aggravated the divisions in Samareño society between uplanders and lowlanders. As indicated earlier, the tension between these groups was moderated by the development of customary laws governing hemp production. However, when the Americans introduced their legal system this favored the wealthy and educated elite and disadvantaged the upland hemp producers (Couttie, 2004). This development further consolidated the power of the island's elite while impoverishing its poorest members.

\section{Conclusion: Ending One Insurgency while Planting the Seeds of Another}

The Americans prevailed in suppressing the insurgency on Samar for a number of reasons. On a tactical level, they refrained from engaging in large-scale cordon and sweep operations and, instead used small-scale reconnaissance-in-force operations ideally suited for the island's rough terrain. They separated the insurgents from the population by depriving the insurgents of food, by implementing a concentration camp system, by providing security for those Samareños who desired protection from the insurgents, and by implanting a policy of non-neutrality forcing people to choose between them or the insurgents. They sought the support of upper-class Samareños and, in so doing, gained the support of those who had the most to lose. Lastly, they had effective intelligence revealing to them the leaders and supporters of the insurgency. This "successful" counterinsurgency campaign came at the price of abuses inflicted upon the population, the destruction of the island's economy, and the entrenchment of the oligarchy on both Samar and across the archipelago.

Perhaps the bitterest legacy of the campaign was the damage inflicted upon the island- the wounding of the wounded land. Today, Samar is one of the poorest islands in the Philippines; the most striking and pervasive feature of Samar," wrote Santos and Lagos (2004), "is poverty." Samar has been "mired in a continuing history of poverty" and it is "a land that continues to bleed from [the] gaping and festering wounds of impoverishment and backwardness" (Santos \& Lagos, 2004). According to the National Statistical Coordination Board (2013), in 
2009, it was estimated that 27 percent of all Filipinos were living in poverty while on Samar that number rose to 50 percent! There has been an emigration of Samarnons off the island in search of better opportunities (Santos \& Lagos, 2004). At the time of the Philippine-American War, Samar's population constituted approximately 16 percent of the archipelago's population; in 2010, this proportion had fallen to less than 2 percent of the Philippine population (National Statistical Coordination Board, 2012). In Metro Manila's sprawling shantytown of Tondo there is a large population of migrants from the Eastern Visayas who have moved to Manila looking for better opportunities (Holden \& Jacobson, 2012). While Samar's high rates of poverty have many causes (the island's vulnerability to typhoons and the long-term decline in hemp prices being two of the most salient), to some extent the poverty of the Samareños must be attributed to the Samar counterinsurgency campaign and its destructive effects.

In the twenty-first century Samar still experiences an insurgency, that of the New People's Army (NPA), the armed wing of the Communist Party of the Philippines (CPP). "Today," wrote Santos and Lagos (2004) the NPA "casts a giant shadow on Samar" and "Samar is among the areas in the Philippines where the NPA is believed to be strong and growing" (Santos \& Lagos, 2004). Colonel Alexander Cabales, deputy commander of the $8^{\text {th }}$ Infantry Division (the Philippine Army Division responsible for the Eastern Visayas) stated "Samar remains a big challenge for the army" (Quirante, 2009) and officials from the AFP have expressed concern that the Samareño provinces have a "considerable presence of rebels" (Gabieta, 2012).

What drives the Samareño NPA is poverty, one of the most powerful grievances motivating people to enter an insurgency. As Griffith $(1961,2005)$ wrote, "A potential revolutionary situation exists in any country where the government consistently fails in its obligation to ensure at least a minimally decent standard of life for the great majority of its citizens." The bulk of those joining the NPA are the rural poor for whom it avails what Santos $(2010,18)$ called "one of the few available livelihood opportunities." The NPA has, as Francia (2010) wrote, "Remained a palpable presence in rural areas, where poverty seemed to be, as it has always been, a permanent feature of the landscape." According to Bello et al. (2009), the NPA "will not go away and will be able to maintain itself as a significant presence in the more geographically marginal and poorer parts of the country." With its rough terrain, and high poverty rates, Samar is precisely such a geographically marginal and poorer part of the country. Its high levels of poverty avail many potential recruits for the movement; De Belder and Vanobberghen (1999) acknowledged this writing, "As one of the poorest regions of the Philippines, Samar has been one of the bulwarks of the Philippine revolution." The NPA has emphasized the recruitment of Samarnons because of their poverty and a 2009 article in Ang Bayan (the CPP newsletter) stated, "More than ever, the dismal economic and political condition in the region is most favorable for waging revolution" (Ang Bayan, 2009).

The insurgency of the NPA on Samar may be the bitter fruit of the Samar counterinsurgency campaign. The Americans defeated the earlier insurgency but, in doing so, gravely damaged the economy of the island. This contributed to Samar remaining a backwater of the archipelago with its high rates of poverty and this has fueled another insurgency. The NPA regards their struggle on Samar as a continuation of that of the Samareños of 1899-1902. A September 2012 Ang Bayan article, commemorating the attack at Balangiga, acknowledged this continuity stating, "The tradition of harnessing the people's armed strength and supporting their armed resistance to grave repression and armed attacks against their communities is very much alive" (Ang Bayan, 2012). By violently ending the insurgency of 1899-1902 the Americans planted the seeds of another.

\section{References}

Ang Bayan. (2009). Backwardness in Eastern Visayas. Ang Bayan, 40(2), 5-6.

Ang Bayan. (2012). Battle of Balangiga, Eastern Samar: Commemorating the Armed Resistance of the Peasant Masses. Ang Bayan, 43(18), 9-10.

Bello, W., Docena, H. de Guzman, M., \& Malig, M. L. (2009). The Anti-Development State: The Political Economy of Permanent Crisis in the Philippines. Manila: Anvil Publishing.

Birtle, A. J. (2004). U.S. Army Counterinsurgency and Contingency Operations Doctrine 1860-1941. Washington: Center of Military History, United States Army.

Blakeley, R. (2009). State Terrorism and Neoliberalism: The North in the South. London: Routledge.

Boot, M. (2002). The Savage Wars of Peace: Small Wars and the Rise of American Power. New York: Basic Books.

Bruno, T. A. (2010). Ending an Insurgency Violently: The Samar and Batangas Punitive Campaigns. Carlisle Barracks, Pennsylvania: U.S. Army War College. 
Constantino, R. (1975). The Philippines: A Past Revisited. Quezon City: Tala Publishing.

Couttie, B. (2004). Hang the Dogs: The True Tragic History of the Balangiga Massacre. Quezon City: New Day Publishers.

Cruikshank, B. (1982). Continuity and Change in the Economic and Administrative History of $19^{\text {th }}$ Century Samar. In A. W. McCoy, \& E. de Jesus (Eds.), Philippine Social History: Global Trade and Local Transformations (pp. 219-249). Quezon City: Ateneo de Manila Univ. Press.

De Belder, B., \& Vanobberghen, R. (1999). Kasama: The Philippine Struggle for Health Care and Liberation through the Eyes of Two Belgian Doctors. Brussels: Anti-Imperialist League,

Environmental Science for Social Change. (1999). Decline of the Philippine Forest. Quezon City: Environmental Science for Social Change.

Francia, L. H. (2010). A History of the Philippines: From Indios Bravos to Filipinos. New York: Overlook Press.

Gabieta, J. (2012). More Troops Sent to Samar Hot Spots. Philippine Daily Inquirer, 17 March, A8.

Galula, D. (1964). Counterinsurgency Warfare: Theory and Practice, London: Praeger Security International.

Gates, J. M. (1973). Schoolbooks and Krags: The United States Army in the Philippines, 1898-1902. Westport, Connecticut: Greenwood Press.

Griffith, S. B. (1961, 2005). Introduction. Mao Tse-Tung. Mineola. In S. B. Griffith, On Guerrilla Warfare (pp. 3-34). New York: Dover Publications.

Haribon Foundation and Birdlife International. (2001). Key Conservation Sites in the Philippines. Makati City: Bookmark.

Holden, W. N. (2009). Ashes from the Phoenix: State Terrorism and the Party-List Groups in the Philippines. Contemporary Politics, 15(4), 377-393. http://dx.doi.org/10.1080/13569770903416422

Holden, W. N. (2011). Neoliberalism and State Terrorism in the Philippines: the Fingerprints of Phoenix. Critical Studies on Terrorism, 4(3), 331-350. http://dx.doi.org/10.1080/17539153.2011.623401

Holden, W. N. (2012). Ecclesial Opposition to Large-Scale Mining on Samar: Neoliberalism Meets the Church of the Poor in a Wounded Land. Religions, 3(3), 833-861. http://dx.doi.org/10.3390/rel3030833

Holden, W. N., \& Jacobson, R. D. (2012). Mining and Natural Hazard Vulnerability in the Philippines: Digging to Development or Digging to Disaster? London: Anthem Press. http://dx.doi.org/10.7135/UPO9781843313960

Kalyvas, S. N. (2006). The Logic of Violence in Civil War. Cambridge: Cambridge University Press. http://dx.doi.org/10.1017/CBO9780511818462

Karnow, S. (1989). In Our Image: America's Empire in the Philippines. New York: Ballantine Books.

Kilcullen, D. (2006). Counterinsurgency Redux. Survival, 48(4), 111-130. http://dx.doi.org/10.1080/00396330601062790

Linn, B. M. (1991). Intelligence and Low-Intensity Conflict in the Philippine War, 1899-1902. Intelligence and National Security, 6(1), 90-144. http://dx.doi.org/10.1080/02684529108432092

Linn, B. M. (1993). The Struggle for Samar. In J. C. Bradford (Ed.), Crucible of Empire: The Spanish American War and its Aftermath (pp. 158-182). Annapolis, Maryland: Naval Institute Press.

Linn, B. M. (2000). The Philippine War: 1899-1902. Lawrence, Kansas: University of Kansas Press.

Linn, B. M. (2003). The US Army and Nation Building and Pacification in the Philippines. In US Army Training and Doctrine Command, Fort Monroe, Virginia and Combat Studies Institute Fort Leavenworth, Kansas (Eds.), Armed Diplomacy: Two Centuries of American Campaigning (pp. 77-89). Fort Leavenworth, Kansas: Combat Studies Institute.

Linn, B. M. (2008). We Will Go Heavily Armed: The Marines Small War on Samar, 1901-1902. In S. S. Evans (Ed.), US Marines and Irregular Warfare, 1898-2007: Anthology and Selected Bibliography (pp. 41-53). Quantico, Virginia: Marine Corps University.

May, G. A. (1987). A Past Recovered. Quezon City: New Day Publishers.

McCoy, A. W. (1999). Closer Than Brothers: Manhood at the Philippine Military Academy. New Haven, Connecticut: Yale University Press. 
McCoy, A. W. (2009). Policing America's Empire: The United States, the Philippines, and the Rise of the Surveillance State. Madison: The University of Wisconsin Press.

Miller, S. C. (1982). “Benevolent Assimilation”: The American Conquest of the Philippines, 1899-1903. London: Yale University Press.

Nagl, J. A. (2005). Learning to Eat Soup with a Knife: Counterinsurgency Lessons from Malaya and Vietnam. Chicago: University of Chicago Press.

National Statistical Coordination Board. (2013) Annual Per Capita Poverty Threshold, Poverty Incidence and Magnitude of Poor Population, by Region and Province: 1991, 2003, 2006 and 2009. Retrieved August 13, 2013, from http://www.nscb.gov.ph/poverty/2009/table_2.asp

National Statistical Coordination Board. Philippine Standard Geographic Code. (2012). Retrieved December 31, 2012, from http://www.nscb.gov.ph/activestats/psgc/listprov.asp

Quirante, N. F. (2009). $8^{\text {th }}$ ID: Samar Remains a Big Challenge in Insurgency. Samar News. 24 September 2009. Retrieved February 4, 2013, from http://www.samarnews.com/news2009/sep/f2445.htm

Rodriguez, R. M. (2010). Migrants For Export: How the Philippine State Brokers Labor to the World. Minneapolis: University of Minnesota Press.

Roth, R. (1981). Muddy Glory: America's Indian Wars in the Philippines, 1899-1935. Hanover, Massachusetts: The Christopher Publishing House.

Santos, P. V. M. (2010). The Communist Front: Protracted People's War and Counter-Insurgency in the Philippines (Overview). In D. Rodriguez (Ed.), Primed and Purposeful: Armed Groups and Human Security Efforts in the Philippines (pp. 17-42). Geneva: Small Arms Survey.

Santos, R. A. M., \& Lagos, B. O. (2004). The Untold People's History: Samar Philippines. Los Angeles, California: Sidelakes Press.

Silbey, D. J. (2007). A War of Frontier and Empire: The Philippine American War, 1899-1902. New York: Hill and Wang.

Thompson, R. (1966). Defeating Communist Insurgency: The Lessons of Malaya and Vietnam, New York: Praeger.

Tiston, R. C. (1984). A Perspective on Dissent in Leyte and Samar. Leyte-Samar Studies, 18, 101-118.

Turse, N. (2013). Kill Anything that Moves: The Real American War in Vietnam. New York: Metropolitan Books.

Tyner, J. A. (2009). The Philippines: Mobilities, Identities, Globalization. London: Routledge.

United States Army and Air Force. (1990). Military Operations in Low Intensity Conflict Field Manual No. 100-20, Air Force Pamphlet No. 3-20. Washington: Departments of the Army and the Air Force.

United States Army and Marine Corps. (2007). The United States Army/Marine Corps Counterinsurgency Field Manual. Chicago: University of Chicago Press.

United States Army Command and General Staff College. (1986). Field Circular: Low Intensity Conflict. United States Army Command and General Staff College: Fort Leavenworth Kansas.

United States Government. (2009). United States Government Counterinsurgency Guide. Washington: United States Government Interagency Counterinsurgency Initiative.

Valentine, D. (2000). The Phoenix Program (2nd ed.) Lincoln: Authors Guild BackinPrint.Com.

Welch, R. E. (1974). American Atrocities in the Philippines: The Indictment and the Response. Pacific Historical Review, 43(2), 233-253. http://dx.doi.org/10.2307/3637551

Young, K. R. (1979). Guerrilla Warfare: Balangiga Revisited. In M. L. C. Vilches (Ed.), Readings in Leyte-Samar History (pp. 249-259). Tacloban City, Philippines: Divine Word University of Tacloban.

\section{Notes}

Note 1. The conflict between the Americans and the Moros (the Muslim inhabitants of Mindanao and the Sulu islands) from 1903 to 1913 was arguably even more violent than the conflict on Samar but the literature on the Philippine-American War regards this as a separate conflict and (almost by default) confines the discussion of 
the Philippine-American War to the conflict between the Christian Filipinos of the rest of the archipelago and the United States (Gates, 1973; Linn, 2000; Miller, 1982; Silbey, 2007).

Note 2. Gates (1973) has received criticism for his praise of the United States Army's conduct during the Philippine-American War (May, 1987). Miller $(1982,277)$ went so far as to refer to his book as an "attempt to whitewash the Army's conduct."

\section{Copyrights}

Copyright for this article is retained by the author(s), with first publication rights granted to the journal.

This is an open-access article distributed under the terms and conditions of the Creative Commons Attribution license (http://creativecommons.org/licenses/by/3.0/). 